\title{
Security Forces, Electoral Conduct and the 2003 General Elections in Nigeria
}

\author{
Kunle Ajayi \\ Department of Political Science, University of Ado-Ekiti, PMB 5363, Ado-Ekiti, Nigeria \\ Mobile No.08036672255, E-mail: kunleajayi566@yahoo.com
}

KEYWORDS Democracy; election rigging; legitimacy; militancy; violence

\begin{abstract}
Leadership succession in Nigeria has before the 2003 elections, assumed a problematic status. This is so because earlier attempts, particularly transition from civilian to civilian ruler-ship, had often resulted in serious national political crisis. The 2003 elections seem to have destroyed the myth associated with such transitional projects. While the 2003 transition might have been seen as successful, opposition political parties, international poll observers, pro-democracy non-governmental organizations and critical analysts have adjudged the elections as lacking in electoral transparency and fairness, and therefore, not devoid of malpractice. Accusing fingers have been pointed to, and aspersions cast at, the security forces especially the police, and the military, which were allegedly ready-made state machinery for perpetuating electoral frauds. The paper intends to investigate the collaborative role of the security forces in allegedly rigging the 2003 elections in favour of the incumbent ruling party. In addition, the paper shall interrogate the expected role of security forces in sustaining and consolidating Nigeria's nascent democracy.
\end{abstract}

\section{INTRODUCTION}

Regular and transparently free and fair elections are key criteria for evaluating whether a nation is democratic or otherwise. Elections provide opportunities for political participation in any political system. The electorate therefore becomes a crucial factor in the selection or choice of political leaders and parliamentary representatives because of their votes. The votes empower the electorate politically, and their votes become an essential determinant of the political commerce in the competition for political office attainment among the parties and candidates involved in political contestations.

The election of state actors has often been problematic in many African states arising from what is at stake politically and economically as derivable benefits including dividends and privileges of political office holding. All this, therefore, makes electoral transitions to assume war-like and zero-sum dimensions among electoral contestants. The stakes particularly bring to the fore the self-succession problematique in Africa. Fatile (2000: 110) aptly captures the succession problem in Africa when he observes that African Heads of State, with one or two exceptions, have been following the same trends of government, and are succeeding themselves in most countries either through constitutional or unconstitutional means. For instance, the leadership could embark on constitutional re-engineering and / or manipulations in order to facilitate his sit-tight political ambition.

Nigeria, like many other countries in Africa, has not been immune against the succession crisis in the continent. The two earlier efforts at civilian-to-civilian succession in the First and Second Republics had been politically disastrous. In other words, prior to the 2003 elections, civilian midwived transitional elections had not only been problematic and controversial, the ensued controversies and violence accompanied with arson and casualties had always instigated military take-over of power. It is within this evaluative perspective that the 2003 general elections could be regarded as a watershed in Nigeria's political history. This is considered so because of the lack of a success in a legacy of electoral succession. However, this submission is devoid of unanimous domestic and external acceptability. Domestic opposition, civil democracy groups and international observers shared an opinion that the 2003 general elections were neither free nor transparent. Security forces were regarded as the winning formula for the ruling People's Democratic Party (PDP), which controls the instrumentalities of legitimate force.

The basic concern of this paper is to examine the role of the security forces in the 2003 elections with a view to determining their level of involvement in the opposition parties' alleged colla- 
borative role with the PDP to rig the elections and thereby secure an illegitimate mandate for the winners. In addressing these problematiques, the rest of this paper is divided into five sections. The first theoretically situates the concept of democracy and its key ingredient, elections in a political system. The second examines the ordinary role of the security forces in a democracy, while the third discusses the 2003 civilian-civilian transitional elections and the role of security forces in the conduct of the elections. Section four identifies the implications of the dysfunctional role by the security forces for democratic consolidation, internal security and foreign investment in Nigeria. Section five concludes the study.

\section{CONCEPT OF DEMOCRACY}

The Nigerian populace, despite the long occupation of the nation's democratic environment by the military and the mental and psychological disorientation suffered under military regimes, still share the intrinsic values of democracy. Anti-military, pro-democracy coalitions, civil organizations and organized labour with the National Democratic Coalition (NADECO) as the arrow-head coupled with extraterritorial democratic forces provided the necessary heat and pressure which made abdication of power by the military in 1999 an uncompromising finality.

Identifying the ideals and values has become an acceptable definitional model in the contemporary understading of democracy. The perspective of Diamond, Linz and Lipset (cited in Abrahamsen, 2000: 68; Ojo, 1999:196-197) seems to be the most popular variation. Accordingly, they describe democracy as a political governing system, which must mandatorily meet three basic conditions.

One is:

Meaningful and extensive competitions among individuals and organized groups (especially political parties) for all effective positions of government power at regular intervals and excluding the use of force.

This conditionality implies that political competition is not restricted to political parties alone. Individuals who are so inclined can contest as independent candidates, even when political parties exist as in the developed democracies notably in the United States. The use of coercive force, either with the instrumentality of legitimate force or thuggery and militancy, constrains free choice of the electorate based solely on their conscience or motivated by party programmes (manifestoes). Thus, political competition accompanied by force therefore erodes the principle of free and fair election.

Two is:

A highly inclusive level of political participation in the selection of leaders and policies, at least through regular and fair elections, such that no major (adult) social group is excluded.

This democratic criterion is an appeal for the liberalization of political participation in the democratic process. The inclusion of all willing political parties and associations in the electoral process without imposition of registration requirements such as fees, geographical spread with identifiable office locations and membership list. Conditional registration of political parties and groups are therefore considered antidemocratic. The Nigerian judiciary affirmed this position when it ruled against imposition of registration fees on political associations by the Independent National Electoral Commission (INEC) before they could compete in the 2003 elections (Soniyi and Alli, 2002: 1-2).

Three is:

A level of civil and political liberties - freedom of expression, freedom of the press, freedom to form and join organizations - sufficient to ensure the integrity of political competition and participation.

Civil and political liberties for individuals and groups must be assured to the extent that citizens can join any political group of their choice. This provision therefore berates the regulated joining of political parties by people under the military regimes of Ibrahim Babangida and Sani Abacha. Freedom of articulation and a free press are ways of assuring expression and publication of diverse opinions by individuals and interest groups that cannot but enrich the beauty of democratic practice.

The definitional analysis of democracy by Huntington (1991: 7) has hinged more strongly on the procedural approach for the selection of decision-makers. According to him, a political system is considered democratic "to the extent that its most powerful collective decision-makers are selected through fair, honest, and periodic elections in which candidates freely compete for votes and in which virtually all the adult 
population is eligible to vote". This view is an amplification of Diamond et al's political participation condition of democracy.

Contemporary scholars on theories of democratic elitism quite associate more with the procedural approach of democracy. The views of Weber and Schumpeter represent this analytical focus. Weber sees democracy primarily as a means of producing an effective political leadership in conditions of a modern bureaucratic society, and apart from their ability to dismiss the ineffective leadership from office, voters are assigned little or no influence over decisionmaking (Abrahamsen, op cit: 69). From this perspective therefore, electoral democracy is seen as confining on the electorate the power to "hire and fire" political leaders. The "firing" power borders on rejecting ineffective and unfit leaders at the polls. It also connotes election as a means of providing legitimacy and mass support for political leaders.

Schumpeter elaborated on the interpretation of democracy as a mechanism for legitimizing the authority of political elite for whom the role of the people in democracy was merely to produce government, and not to choose politicians who execute their will (ibid). To put Schumpeter in correct perspective, he succinctly argues that democracy;

Does not mean and cannot mean that the people actually rule in any obvious sense of the terms 'people' and 'rule'. Democracy means only that the people have the opportunity of accepting or refusing the men who are to rule them. Now, one aspect of this aspect may be expressed by saying that democracy is the rule of the politician (Ibid).

Ogunsanwo (n.d) expresses some level of discomfortability with the reductionist theses of democracy, which emphasize the selection approach. According to him, elections alone do not make democracy. Though, he agrees that universal adult suffrage is a sine qua non and its absence would definitely lead some to question the type of democracy being practised (ibid: 2). He believes that democracy should also emphasize on the basic right of the people to form political associations of their own as platforms for canvassing for votes. It is on this basis that Ogunsanwo berates the formation of political parties for the people by military regimes in the 1999 transitional elections in Nigeria and the subsequent denial of registration for some political associations by INEC in 2002.
Nzogola - Ntalaya (2001: 21) also contends that elections alone are not a guarantee of democracy. He sees democracy as a means of social transformation in the sense of meeting people's aspirations, which can be identified as meeting people's needs and welfare. It is within this utility value of democracy that Obasanjo (2004: 24) opines that democracy is about people. He argues that;

Democracy is about people. It is about community and it is about truth, justice, cooperation and collective efforts at building and nurturing open societies and institutions in the interest of all (ibid)

Obasanjo further opines that, democracy is evidenced in the multiplicity of functioning political parties, periodic election, and adherence to constitutionalism, and that democracy is about protecting all in society, guaranteeing citizenship and participation and holding leaders that emerged from the democratic process accountable at all times as they serve the people (ibid).

In essence, democracy is about serving the people, hence, the elementary interpretation of democracy is about the people for the people. People elect representatives in government to be able to cater for their interests. It in a way, implies that the electorate's votes are regarded as sacred mandates. It is on the basis of this sacred mandate and the electioneering promises made to the electorate that political leaders are appraised and made accountable. The idea of good governance is in part, measured by the amount of dividends of democracy enjoyed by the people.

Most often, especially in Africa, adherence to constitutionalism in the electoral process is a problem. Election may be free but not fair, or both. Again, the election may be peacefully conducted, yet may not be free or fair as it may be accompanied by malpractice including rigging and intimidation of the electorate, particularly by the ruling party, which controls the machinery of state. Amnesty International describes intimidation against the electorate and the civil populace as "violence against democracy" (Nzongola-Ntalaja, op cit 23). Besides intimidation, other manifestations include police repression of democracy and human rights activists, and systematically organized acts of violence against the democracy movement, ethnic cleansing, wholesale massacres, and genocide (ibid, 24). Nzongola-Ntalaja opines that violence against 
democracy has the effect of derailing it altogether (ibid). Why do political parties and electoral contestants rig elections? Why the desperation to rig elections and win at all costs? The propensity to rig elections in the developing world is often propelled by the winning at all costs attitude arising basically as a result of the general poverty ravaging most developing countries. Severe economic hardships and mass unemployment thereby make life difficult for most citizens and strengthen poverty in these countries. Many, particularly the political elite, see the political sector and political office holding, as means of livelihood. Therefore, rather than considering political office holding as opportunity to serve the people and the nation, it has erroneously come to be perceived as a vocation and an avenue for making easy wealth. Besides, the fear of post-political office career constitutes a problem to a free and fair election. The fear of what becomes of the office holder after service as a president or governor, parliamentarian or council chairman is a motivating factor for rigging elections. Most political office-holders do not want to lose the benefits, perquisites, respect and social status conferred by public office holding. In general, the political economic factor is the over-riding cause of the electoral zero-sum game and politics of exclusion in the developing economies.

\section{THE 2003 ELECTIONS AND SECURITY FORCES}

The police and the military have constitutional roles to play in any democracy. Section 215 (3) of the 1999 Nigeria Constitution spells out that the Nigeria Police Force is saddled with the maintenance of public safety and public order. The police is responsible for the arrest of crime and criminals, and prosecution of criminals. It has the responsibility of protecting lives and private and public property. The Nigeria Police is also constitutionally empowered to protect harbours, waterways, railways and airfields (FRN, 1999 section 214 [2c]).

In the same vein, the 1999 constitution recognizes the role of the Armed Forces in the nation's constitutional democracy. According to section 217 (2), the Armed Forces have responsibilities of:

a. defending Nigeria from external aggression

b. maintaining its territorial integrity and securing its borders from violation on land, sea or air

c. suppressing insurrection and acting in aid of civil authorities to restore order when called upon to do so by the president

d. performing such other functions as may be prescribed by an Act of the National Assembly

The Armed Forces constitute a deterrent force against any external aggression on Nigeria. They defend the nation's sovereign integrity and protect the people of Nigeria.

The role of the police and armed forces in the contemporary times especially since the 1950s, has transcended the original traditional/ constitutional duties within and outside the shores of their countries. The police and the military have been engaged in international peacekeeping operations. Peacekeepers perform the military duties of inter-positioning and monitoring cease-fire lines between warring groups. Since the end of the cold war in about 1989, however, the responsibilities of peacekeepers have changed from the traditional military sphere. The role of modern peacekeeping missions includes tasks such as human rights monitoring, civilian police monitoring, electoral assistance and election monitoring, voter education and democratization programmes (De Coning, 2001: 17). In essence, the police and armed forces can be used to provide and maintain security for voters and electoral officials during elections and thereby provide a free and conducive environment for the conduct of elections

The imperative for providing adequate security during the 2003 elections was motivated by the general pre-election premonition and apprehension that pervaded the polity. Screaming headlines by national dailies only fuelled people's fear of outbreak of violence during the election. For instance, Thisday (2003: 41) newspaper, had as its headline; "2003: the Dangers Ahead". The paper expressed the fear that politicians who were afraid of their electoral chances might resort to the use of ethnic militia. The paper further reported that because of the deteriorating security situation in the country, soldiers had been deployed for normal police duties (Olaniyonu et al., 2003: 41).

Assumably, based on the adverse security situation across the nation, thousands of police, anti-riot policemen, prison guards and fiercelooking soldiers in combat gears and equipped 
with armoured tanks were deployed throughout the election days.

The presidential, governor-ship and parliamentary elections were conducted as scheduled. The presidential poll result showed that the incumbent president, Olusegun Obasanjo of the Peoples Democratic Party (PDP) won the election with a total vote of $24,456,140(61.94 \%)$ and having scored $25 \%$ or more in 32 states of the Federation (see Table 1). Obasanjo's closest rival, Buhari Muhammadu of the All Nigeria People's Party (ANPP) scored 12,710,022 (or $32.19 \%$ of total votes) and had $25 \%$ or more of the votes in 19 states. The ruling party, PDP, also had over-whelming victories in the Senate and
House of Representatives (HOR) elections. In the 109 seats Senate, the party won 73 seats, while ANPP had 28 seats and Alliance for Democracy (AD) 6 seats. The remaining 27 political parties that contested the election won no seats (see Table 2). The HOR election also gave victory to the PDP with 213 seats. The ANPP and AD had 95 and 31 seats respectively (see Table 3). The results of the states' governor-ship election also shows that the PDP won in twenty-eight states, while the ANPP won in seven states and AD, one state (The Editor, 2003: 1-2). All other parties did not win a state.

The results of the elections have since remained very controversial and made subjects

Table 1: Nigeria Overall Presidential Election

\begin{tabular}{|c|c|c|c|c|}
\hline Party & $\begin{array}{l}\text { Candidates } \\
\text { votes }\end{array}$ & $\begin{array}{c}\text { Total } \\
\text { valid } \\
\text { scored }\end{array}$ & $\begin{array}{l}\% \text { of } \\
\text { votes }\end{array}$ & Quotas \\
\hline \multirow[t]{2}{*}{ ANPP } & Pres: Buhari Muhammadu & & & \\
\hline & Vice: Okadigbo chuba William Malachy & $12,710,022$ & 32.19 & 19 of 25 \\
\hline APGA & $\begin{array}{l}\text { Pres: Ojukwu Chukwuemeka Odumegwu } \\
\text { Vice: Bayero Sani Ibrahim }\end{array}$ & $1,297,445$ & 3.29 & 2 of 25 \\
\hline \multirow[t]{2}{*}{ APLP } & Pres: Okereke Osita Emmanuel & & & \\
\hline & Vice: Abdullahi Turuku Alhaji & 26,921 & 0.07 & 0 of 25 \\
\hline ARP & $\begin{array}{l}\text { Pres: Yahaya G.K. Ezemue Ndu } \\
\text { Vice: Hajia Asmau Aliyu Mohammed }\end{array}$ & 11,565 & 0.03 & 0 of 25 \\
\hline \multirow[t]{2}{*}{ BNPP } & Pres: Nnaji Ifeanyichukwu Goodwill & & & \\
\hline & Vice: Suleiman Mohammed Awwal & 5,987 & 0.02 & 0 of 25 \\
\hline DA & Pres: Ferreira, Antonia Abayomi Jorge & 6,727 & 0.02 & 0 of 25 \\
\hline $\mathrm{JP}$ & $\begin{array}{l}\text { Pres: Christopher Ogenebrorie Okotie } \\
\text { Vice: Habib Mairo Baturiya (Mrs.) }\end{array}$ & 119,547 & 0.30 & 0 of 25 \\
\hline LDPN & $\begin{array}{l}\text { Pres: Chief Christopher Pere Ajuwa } \\
\text { Vice: Mohammed Nasir }\end{array}$ & 4,473 & 0.01 & 0 of 25 \\
\hline \multirow[t]{2}{*}{ MDJ } & Pres: Yusuf Muhammed Dikko & & & \\
\hline & Vice: Chief Meldrof Obiene Okilo & 21,403 & 0.05 & 0 of 25 \\
\hline MMN & $\begin{array}{l}\text { Pres: Major Mojisola Adekunle Obasanjo (rtd) } \\
\text { Vice: Mohammed Ibrahim }\end{array}$ & 3,757 & 0.01 & 0 of 25 \\
\hline NAC & $\begin{array}{l}\text { Pres: Agoro (Dr) Olapade (Roland Aremo) } \\
\text { Vice: Aminu Garbati Abubakar }\end{array}$ & 5,756 & 0.01 & 0 of 25 \\
\hline NAP & $\begin{array}{l}\text { Pres: Tunji Braithwaite } \\
\text { Vice: Hajia Maimunatu Lata Tombai (MON) }\end{array}$ & 6,932 & 0.02 & 0 of 25 \\
\hline \multirow[t]{2}{*}{$\mathrm{NCP}$} & Pres: Ganiyu Fawehinmi & & & \\
\hline & $\begin{array}{l}\text { Vice: Jerome (Jerry) Tala Gopye } \\
\text { Pres: Sen. Ike Omar Sanda Nwachukwu }\end{array}$ & 161,333 & 0.41 & 0 of 25 \\
\hline NDP & Vice: Habu Fari Aliyu & 132,997 & 0.34 & 0 of 25 \\
\hline \multirow[t]{2}{*}{ NNPP } & Pres: Dr. Kalu Idika Kalu & & & \\
\hline & Vice: Jawi Abdul Rahman Paga & 23,830 & 0.06 & 0 of 25 \\
\hline PAC & $\begin{array}{l}\text { Pres: Mrs Sarah N. Jibril } \\
\text { Vice: Chief Elemosho Babatunde Tajudeen }\end{array}$ & 157,560 & 0.40 & 0 of 25 \\
\hline PDP & $\begin{array}{l}\text { Pres: Chief Olusegun Obasanjo } \\
\text { Vice: Alh. Atiku Abubakar }\end{array}$ & $24,456,140$ & 61.94 & 32 of 25 \\
\hline PMP & $\begin{array}{l}\text { Pres: Nwankwo Agwucha Arthur } \\
\text { Vice: Batubo Benett Raymond }\end{array}$ & 57,720 & 0.15 & 0 of 25 \\
\hline PRP & $\begin{array}{l}\text { Pres: Musa Abdulkadir Balarabe } \\
\text { Vice: Okafor Ernest Ngozi }\end{array}$ & 100,765 & 0.26 & 0 of 25 \\
\hline UNPP & $\begin{array}{l}\text { Pres: Sen. Nwobodo Jim Ifeanyichukwu } \\
\text { Vice: Goni Mohammed }\end{array}$ & 169,609 & 0.43 & 0 of 25 \\
\hline
\end{tabular}

Source: http: //www.inecnigeria.org/2003elections/results/presidential/summary.htm 
Table 2: Nigeria Overall

\begin{tabular}{|c|c|c|c|}
\hline $\begin{array}{l}\text { Senate } \\
\text { party }\end{array}$ & $\begin{array}{r}\text { Senate } \\
\text { district won }\end{array}$ & $\begin{array}{r}\text { Total valid } \\
\text { scored votes }\end{array}$ & $\%$ of votes \\
\hline$\overline{\mathrm{AD}}$ & 6 & $2,828,082$ & 9.74 \\
\hline ANPP & 28 & $8,091,783$ & 27.87 \\
\hline APGA & 0 & 429,073 & 1.48 \\
\hline APLP & 0 & 14,004 & 0.05 \\
\hline ARP & 0 & 9,138 & 0.03 \\
\hline BNPP & 0 & 6,782 & 0.02 \\
\hline $\mathrm{CPN}$ & 0 & 7,296 & 0.02 \\
\hline DA & 0 & 6,476 & 0.02 \\
\hline GPN & 0 & 4,722 & 0.02 \\
\hline JP & 0 & 28,887 & 0.10 \\
\hline LDPN & 0 & 5,419 & 0.02 \\
\hline MDJ & 0 & 6,468 & 0.02 \\
\hline MMN & 0 & 3,393 & 0.01 \\
\hline NAC & 0 & 4,392 & 0.02 \\
\hline NAP & 0 & 7,620 & 0.03 \\
\hline $\mathrm{NCP}$ & 0 & 148,157 & 0.51 \\
\hline ND & 0 & 14,527 & 0.05 \\
\hline NDP & 0 & 459,462 & 1.58 \\
\hline NMMN & 0 & 3,914 & 0.01 \\
\hline NNPP & 0 & 11,533 & 0.04 \\
\hline NPC & 0 & 12,224 & 0.04 \\
\hline NRP & 0 & 13,227 & 0.05 \\
\hline $\mathrm{PAC}$ & 0 & 140,854 & 0.49 \\
\hline PDP & 73 & $15,585,538$ & 53.69 \\
\hline PMP & 0 & 50,765 & 0.17 \\
\hline PRP & 0 & 204,929 & 0.71 \\
\hline PSD & 0 & 10,482 & 0.04 \\
\hline PSP & 0 & 117,295 & 0.40 \\
\hline UDP & 0 & 13,960 & 0.05 \\
\hline UNPP & 0 & 789,705 & 2.72 \\
\hline
\end{tabular}

Source: http: //www.inecnigeria.org/2003elections/ results/ presidential/summary.htm

of litigation. The ANPP and the other 28 political parties that contested the elections alleged the PDP of mass rigging across the nation. The parties alleged that the PDP used its control of the police and armed forces to rig the elections. The varied reports of both the local and international election observers who were on the field on the election days seem to lend credence to the allegations of the opposing parties.

For instance, the 30,000 Justice, Development and Peace Committee (JDPC) local team monitored and observed the elections. In its final reports, it, in part, appreciated the beefing up of security by the police, military and para-military forces. According to it, their presence helped to maintain law and order in some parts of the country where there had been high rate of violence resulting in deaths (JDPC, 2003: 20). The JDPC however noted that the presence of the security agencies dampened the spirits and confidence of voters in many other parts of the country (ibid). The team specifically noted that:

Security agents were out to collaborate with
Table 3: Nigeria Overall

\begin{tabular}{|c|c|c|c|}
\hline $\begin{array}{l}\text { House of } \\
\text { representatives } \\
\text { party }\end{array}$ & $\begin{array}{l}\text { Fede } \\
\text { cons } \\
\text { won }\end{array}$ & $\begin{array}{l}\text { Total } \\
\text { votes }\end{array}$ & $\begin{array}{r}\% \text { of } \\
\text { valid } \\
\text { scored } \\
\text { votes }\end{array}$ \\
\hline $\mathrm{AD}$ & 31 & $2,711,972$ & 9.28 \\
\hline ANPP & 95 & $8,021,531$ & 27.44 \\
\hline APGA & 2 & 397,147 & 1.36 \\
\hline APLP & 0 & 12,936 & 0.04 \\
\hline ARP & 0 & 8,746 & 0.03 \\
\hline BNPP & 0 & 5,703 & 0.02 \\
\hline $\mathrm{CPN}$ & 0 & 6,738 & 0.02 \\
\hline $\mathrm{DA}$ & 0 & 6,096 & 0.02 \\
\hline GPN & 0 & 4,257 & 0.01 \\
\hline JP & 0 & 27,751 & 0.09 \\
\hline LDPN & 0 & 4,966 & 0.02 \\
\hline MDJ & 0 & 11,175 & 0.04 \\
\hline MMN & 0 & 2,816 & 0.01 \\
\hline NAC & 0 & 4,430 & 0.02 \\
\hline NAP & 0 & 7,620 & 0.02 \\
\hline $\mathrm{NCP}$ & 0 & 140,401 & 0.48 \\
\hline ND & 0 & 21,854 & 0.07 \\
\hline NDP & 1 & 561,161 & 1.92 \\
\hline NMMN & 0 & 3,154 & 0.01 \\
\hline NNPP & 0 & 8,779 & 0.03 \\
\hline NPC & 0 & 10,687 & 0.04 \\
\hline NRP & 0 & 13,500 & 0.05 \\
\hline PAC & 0 & 137,328 & 0.47 \\
\hline PDP & 213 & $15,927,807$ & 54.49 \\
\hline PMP & 0 & 29,100 & 0.10 \\
\hline PRP & 1 & 222,938 & 0.76 \\
\hline PSD & 0 & 10,889 & 0.04 \\
\hline PSP & 1 & 96,550 & 0.33 \\
\hline UDP & 0 & 12,695 & 0.04 \\
\hline UNPP & 2 & 803,432 & 2.75 \\
\hline
\end{tabular}

Source: http: //www.inecnigeria.org/2003elections/ results/presidential/summary.htm

and protect the ruling party. In most of the polling stations they did nothing to prevent hijacking of ballot papers by political thugs ... Rigging was peacefully done in the form of ballot box stuffing by mainly PDP party agents collaborating with polling officials (ibid, 31).

The climax of the JDPC monitoring reports on the use and misuse of security agencies was the observation that "the ruling party in each of the two geo-political zones (South-South and SouthEast), with the connivance of some INEC officials and the security officers, unleashed fearsome intimidation against its opponents and succeeded in carrying out massive rigging of elections in a manner that was reminiscent of the dark ages" (ibid, 37). In general, the JDPC reports indicted the security forces during the elections.

In the same manner, the Citizens Forum $(\mathrm{CF})$ observed in its report that the elections were massively rigged and manipulated and therefore called on President Obasanjo and the state 
governors to resign (Oladipo, 2004: 1). The European Union (EU), American and the Commonwealth observer teams seem to share the same view with the local observers. The 118-EU observer team noted that serious irregularities and fraud, which undermined the integrity of the electoral processes, marred the elections (Alli et al., 2003: 1-2). The 22-member Commonwealth observer team, despite awarding a pass mark for the elections nevertheless noted in its assessment statement signed by the Mission Head, Salim Ahmed Salim, that:

But in certain states, the election did not go well. In parts of Enugu and in Rivers States, proper electoral processes appear to have broken down and there was intimidation (ibid).

The report of the Washington-based National Democracy Institute (NDI) was in tandem with the other election observers. The Institute noted with very serious concern the legitimacy of the results in certain constituencies because of observed "ballot stuffing, rigging, voter intimidation, violence and fraud particularly in the South-East and South-South zones" (ibid, 2). The International Republican Institute (IRI) of America described the elections as "outright fraud" in Cross River, Imo and Rivers States (ibid). In general, both opposition parties and election observers condemned the dysfunctional roles of the security agents. The belief is therefore that security agents aided the victory of the ruling PDP in all the facets of the elections. Opposition parties' aspersion on the role of the security forces was further enhanced by the allegation that the Police Force specifically sent out an instruction signal titled "Instruction for Strict Compliance" to all its state commands that its officers and men should ensure the success of the PDP in the elections (Ayoola, 2004: 1-2).

\section{PATTERNS OF ELECTORAL MALPRACTICE BY SECURITY AGENTS}

The observed roles of the security forces in perpetuating electoral malpractice and fraud include:

i. Collusion with politicians to scare opponents from polling centers

ii. Receiving bribes from politicians to stuff ballot boxes

iii. Collusion with political party agents and thugs to stuff ballot boxes

iv. Failing to act in the face of violence and rigging v. Personally thumb-printing ballot papers

vi. Abandonment of/absence from, attached polling centers

vii. Sporadic shooting into the air to scare away genuine voters, and in the process, ballot boxes already stuffed were substituted for the empty ones

viii. Illegal arrest and detention of political opponents at the eve of election and election days

ix. Sporadic shooting into the air at the house of opponents before and during election days to prevent them from any effective mobilization of supporters and the electorate

$\mathrm{x}$ Harassing of voters at polling booths including beating and jack booting thereby infringing on their human rights.

xi. Allowing hijacking of ballot papers and boxes by political thugs.

\section{POST-ELECTION LITIGATIONS}

Based on the observed roles of the security forces as aiding the ruling PDP's victory at the centre and state levels, the coalition of twentynine opposition parties under the umbrella of the Conference of Nigerian Political Parties (CNPP) and more strongly, the ANPP and AD called for the rejection of the election results (Alli et al., op cit: 1-2; Ekundayo and Koleoso, 2004: 7). While the opposition parties were neither dissuaded nor persuaded by the statement of the Police Commission to probe the electoral fraud collusion by the police force, the presidential, some gubernatorial and parliamentary results have been challenged at Election Tribunals by opposing parties and candidates.

Muhammadu Buhari of the ANPP and Dikko Yusufu of the Movement for Democratic Justice (MDJ) have challenged the election victory by President Obasanjo. While the litigation on the presidential result is still in progress, some of the petitions at other levels have been decided. For instance, the Election Tribunal in Adamawa State has nullified the PDP gubernatorial victory and ordered a run-off election in 14 of the 21 local governments in the state. The tribunal ruled that the governor, Boni Haruna was "not validly elected". Stating "it was evident that thugs and security officials acted in favour of PDP to disallow agents of ANPP from performing their roles during the last general elections in various local government areas (Akinadewo, 2004: 1-2). The PDP has 
however appealed against the judgement. The victories of governors Peter Odili of Rivers State and Attah of Akwa Ibom State were also challenged but resolved in their favour (Daniel, 2004: 6). Some other petitions on the election results are at varied stages.

\section{IMPLICATIONS OF SECURITY FORCES' INVOLVEMENT IN ELECTORAL MISCONDUCT}

The misuse of security agencies to facilitate electoral misconduct portends some serious implications for the nation's security institutions and democratic consolidation and stability

Ordinarily, security forces are supposed to be seen as national symbols and are actually expected to act as such by being impartial in their civil-military relations. The forces are agents and servants of the civil society. When the security forces so act, it enhances the reposition of confidence in them and thereby they are truly seen as impartial non-political state machinery, which derives funding from the people's taxes. Contrarily, the political use of the forces by the ruling party may ignite lack of public confidence in the security forces and thereby merely seen by a large section of the public and opposition parties as tools of oppression, marginalization and dishonesty in the hands of the ruling elite.

Seeking counter-balance security measures by members of the public, and especially political parties and electoral contestants becomes an appeal. Once the public loses confidence in the ability of security forces to provide security and ensuring their freedom of choice through the ballot box, then, there may be recourse to individual self-defence through either selfarmament or joining militant groups, which will only compound the insecurity situation the nation is currently going through. At a greater level, opposition political parties and politicians/ contestants may decide to float armed wings for their parties or sponsor emergence of militia groups to provide security for them and act as balance of power or balance of terror against state security forces during campaign periods and at polling booths. From hindsight, there was the existence of various private security vanguards, which were engaged in perpetrating political violence against opponents during the Second Republic. The escalating political violence, particularly after the 1983 general elections, and the attendant break down of law and order, in part, motivated the military coup against the Shagari democratic regime in December, 1983.

Besides sponsorship of armed military forces by politicians, the realization of the potency of security forces as weapons of electoral victory has brought another negative security dimension to the electioneering process, which involves the use of fake policemen and soldiers during election days. In order to ensure a fool-proof election rigging plan, opposition politicians who have no opportunity of utilizing state security agents at the disposal of the ruling party, have often engaged in procuring the services of fake policemen and soldiers wearing the normal official uniforms in order to deceive the people and provide a conducive environment for rigging through intimidation and harassment. For instance, there were reported cases of fake policemen in Edo and Ekiti states in the March/ April, 2004 council elections ( Olufowobi and Adebayo, 2004: 7 - 8; Otokiti,2004:12).

Sponsorship of armed militiamen and floating of fake security forces by politicians as a leverage to the misuse and abuse of state security forces portends a much greater danger for the nation's internal security. This is in the area of escalating small arms proliferation in the country for political reasons. Politicians who are afraid of their electoral chances were reported to have funded arms production (Owete, 2002: 1-2). The existence of illegal armed factories manufacturing AK47 rifles and ammunitions had also been uncovered across the nation by secret security operatives (Olatunji, 2004: 14). The arms proliferation phenomenon has contributed to the increase in the tempo of political assassinations and violent ethnic and religious conflicts pervading the country.

The cumulative outcome of the overall consequences of the misuse of security forces by the ruling party for electoral gains is the ceaseless agitation by some state governors and politicians for the creation of state police. Prominent in this call is the Lagos State Governor, Ahmed Tinubu. Only Tinubu, among the hitherto six Southwest AD governors, survived the PDP 'political conquest' in the 2003 gubernatorial elections. The experience of the former AD governors in the 2003 election and the 2004 council polls has compelled Tinubu to vehemently call for a state police arguing that the present police lacks the capacity to meet Nigeria's 
security needs (Gbadamosi, 2004: 1-2). The calls for state police is an indication of loss of confidence in the Nigeria Police force, a development that may ignite a repulse of the police superintending over future elections by aggrieved politicians and state governors, and thereby discrediting the electoral process and importantly undermine the growing democracy.

Election rigging whittles down the power of the electorate over elected officials. Election is the most important weapon of the electorate to enforce accountability and control on elected officials. Election also signifies a contractual mandate between the electorate and the elected. The electorate gave the latter their mandate based on the campaign promises made by the elected officials. The officials therefore owe the electorate the responsibility of meeting such electoral promises and in doing so, the dividends of democracy are made available to the electorate. The electoral success of political leaders in future elections is therefore determined by their performance in office. Leaders who performed creditably are given a new mandate, while those who failed to meet up with their electioneering promises are rejected at the polls.

Political officials elected through illegal means have no mandate of the people and by implication, do not owe the electorate the fulfillment of any campaign commitments. Rigging therefore denies the elected leaders the popular mandate of the people, and at the same time, the electorates are deprived adequate attention and concern for their welfare by political officials who were rigged into power.

\section{CONCLUDING REMARKS}

The emerging dysfunctional role of the security forces in the 2003 elections and the subsequent 2004 council polls mark a clear departure from their traditional responsibilities. The opposition parties and election observers share the uncompromising opinion that the electoral victory of the ruling PDP in the elections was facilitated by the use of security forces to destabilize the opposition before and during the elections. It suffices to say that whichever party wins the presidency and controls the armed forces, has a greater propensity to win elections in Nigeria and be returned to power through electoral manipulations with the security forces as facilitators.
The subversion of the normal electoral process through whatever means by either the ruling party or other parties can only erode the legitimacy of election as a means of managing political and leadership change. Elections perceived by the electorate as either free but not fair or both, or the results announced do not reflect the true wishes of the people will only lead to the enthronement of an illegitimate regime and leaders without a popular mandate. At best, such regime and leaders may have authority and power without legitimacy, thereby lacking the moral right to rule. However, the most pitiable outcome of rigged elections is the loss of faith in the electoral process altogether. What will follow are political apathy and cynicism on the part of the people.

Finally, besides the fact that the system will be intermittently punctuated with eruptive violence which can lead to the disruption of the system and ultimately, the destruction of the emerging democracy through a coup d'etat by the nation's military noted for a character of political restiveness and notoriety for involvement in politics, thereby, throwing the nation back to an abyss of political darkness. The other problem is the issue of professionalism. Erosion of professionalism is a major problem of Nigeria's security forces, particularly the military, for their foray into politics over the years. The forces have become politicized rather than being depoliticized and adhering strictly to their constitutional, traditional roles of tendering the nation's security. The forces therefore need to undergo a regime of partisan political disorientation incorporating programmes of training and re-training on their expected constitutional roles in the new reality of the nation's emerging democracy and thereby charting a new course in civil-military relations. The re-orientation programme must also reemphasize the need to observe professionalism at all times. Renewed sense of professionalism founded on sound political education will ensure making the security institutions see themselves as symbols of national unity and impartial arbiters, rather than political tools in the hands of the ruling party for perpetrating political illegalities, and dishonesty during electoral contests.

\section{REFERENCES}

Abrahamsen, R. 2000. Disciplining Democracy: Development Discourse and Good Governance in Africa. London: Zed Books,. 
Akinadewo, G. 2004. "Tribunal Removes Adamawa Governor." The Comet, Lagos, March 25, pp. 1-2.

Alli, Y. et al 2003. "Obasanjo Wins Second Term, EU, Commonwealth disagree." The Punch, Lagos, April 23, pp. 1-2.

Ayoola, B. 2004. "Obasanjo versus Buhari: Police deny order to support PDP." The Comet, Lagos, March 30 , pp. $1-2$

Daniel, S. 2004. "Guber Poll: Awuse loses again to Odili." Saturday Punch, Lagos April 17, p. 6

De Coning C. 2001. "Peace and Peace-keeping." Conflict Trends, South Africa, 3: 17.

Ekundayo, T. and R Koleoso 2004. "Ekiti AD rejects byeelection result." The Comet, Lagos, March 5, p.7

Fatile, J.O. 2000. "Self-Succession and Civilianization of the Military Hierarchy: Implications for Democracy in Nigeria." Journal of Policy Initiatives, 3(1): 110.

FRN 1999. Constitution of the Federal Republic of Nigeria,Abuja. Nigeria: Federal Government Press.

Gbadamosi, W.H. 2004. "Dikibo's Murder Throws Up Questions." The Comet, Lagos February 10, pp. 1-2.

Huntington, S.P. 1991. The Third Wave: Democra-tization in the Late Twentieth Century. London: University of Oklahoma Press.

JDPC 2003. Final Report on the Observation of the 2003 General Elections in Nigeria. Lagos: Catholic Secretariat of Nigeria Nzongola-Ntalaya, G 2001.
"The Democracy Project in Africa: The Journey so Far." The Nigerian Social Scientist, 4(1): 21, 23-24.

Obasanjo, O. 2004. "We must Remember Democracy is about People." The Comet, Lagos March 26, p. 24.

Ojo, O. 1999. "Military and Language and Democratization in Nigeria", (pp. 193-215) in Dele Olowu, A. Williams and K. Somerekun (eds.) Governance and Democratization in West Africa. Dakar: CODESRIA.

Olaniyonu, Y., K.Ologbodiyan, E. Ugwu and T. Sanni. 2003. "2003: The Dangers Ahead." Thisday, Lagos February 10, p. 41.

Olatunji, J.S. 2004. "SSS Uncovers Illegal Arms Factory." Saturday Tribune, Ibadan, March 20, p.14.

Olufowobi, S and B. Adebayo. 2004. "Fake Police on the Prowl." Sunday Punch, March 21, pp.7-8.

Otokiti, S. 2004. "Twists and Turns in Council Polls." The Comet on Saturday, Lagos, April 3, p12.

Owete, F. 2002. "2003: IG raises alarm." Saturday Punch, Lagos December 21, pp.1-2.

Soniyi, T. and Y. Alli. 2002. "Party registration: Supreme backs Gani, others." Saturday Punch, November 9, pp. 1-2

The Editor 2003. "PDP wins in 28 States... ANPP, seven." The Punch, Lagos, April 22, pp. 1-2.

This Day. 2003. "2003: The Dangers Ahead" This Day, Lagos. February 10, p. 10. 